\title{
Direct Torque Control for Three-Level Neutral Point Clamped Inverter-Fed Induction Motor Drive
}

\author{
Manoj Kumar Sahu \\ Associate Professor, HOD \\ Department of EEE \\ Hi-Tech College of Engineering \\ BPUT, Odisha, India \\ manojsahu.bls@gmail.com
}

\author{
Anup Kumar Panda \\ Professor \\ Department of EE \\ NIT Rourkela, \\ Odisha, India, \\ akpanda.ee@gmail.com
}

\author{
Bibhu Prasad Panigrahi \\ Professor, HOD \\ Department of EE \\ IGIT Sarang, \\ Odisha, India \\ bibhu89@yahoo.com
}

\begin{abstract}
Direct torque control (DTC) is a control technique in AC drive systems to obtain high performance torque control. The classical DTC drive contains a pair of hysteresis comparators and suffers from variable switching frequency and high torque ripple. These problems can be solved by using space vector depending on the reference torque and flux. In this paper the space vector modulation technique is applied to the three-level Neutral Point Clamped (NPC) inverter control in the proposed DTC-based induction motor drive system, resulting to a significant reduce of torque ripple. Three-level neutral point clamped inverters have been widely used in medium voltage applications. This type of inverters have several advantages over standard two-level VSI, such as greater number of levels in the output voltage waveforms, less harmonic distortion in voltage and current waveforms and lower switching frequencies. This paper emphasizes the derivation of switching states using the Space Vector Pulse Width Modulation (SVPWM) technique. The control scheme is implemented using Matlab/Simulink. Experimental results using dSPACE validate the steady-state and the dynamic performance of the proposed control strategy.
\end{abstract}

Keywords- Direct torque control; nutral point clamped(NPC); space vector pulse width modulation (SVPWM); three-level inverter

\section{INTRODUCTION}

The direct torque control (DTC) method has emerged as an alternative to Field Oriented Control (FOC) method for high performance ac drives since it was firstly proposed in the mid1980 [1-2]. The merits of DTC are fast torque response, simple structure (no need of complicated coordinate transformation, current regulation or modulation block), and robustness against motor parameter variation [3-7].

On the other hand, multi-level inverters have become a very attractive solution for high power application areas [8-11]. The three-level Neutral Point Clamped (NPC) inverter is one of the most commonly used multi-level inverter topologies in high power ac drives. By comparing to the standard two-level inverter, the three-level inverter presents its superiority in terms of lower stress across the semiconductors, lower voltage distortion, less harmonic content and lower switching frequency [12]. Due to the above mentioned merits, the threelevel inverter fed DTC motor drive has become an important research topic in research and academic community over the past decade [13-21].

A variety of techniques have been proposed to overcome some of the drawbacks present in DTC [22]. Some solution proposed are: DTC with the Space Vector Pulse Width Modulation (SVPWM)) [23]; the use of a duty-ratio controller to introduce a modulation between active vectors chosen from the look-up table and the zero vectors [24-25]; use of artificial intelligence techniques, such as neuro-fuzzy controller with SVPWM [26-28]. However, the complexity of the control is considerably increased.

Among various modulation techniques for a multi-level inverter, SVPWM is an attractive candidate due to the following merits. It directly uses the control variable given by the control system and identifies each switching vector as a point in complex space. It is suitable for Digital Signal Processor (DSP) implementation and able to optimize switching sequences.

In this paper, Direct Torque Control-Space Vector Modulation (DTC-SVM) with three-level NPC voltage source inverter is investigated. The proposed scheme is described clearly. Simulation and experimental results are reported to demonstrate its effectiveness. The entire control scheme is implemented using Matlab/Simulink and hardware realization is done using dSPACE. The simulation and experimental results of the proposed scheme are found to be in close agreement, thereby indicating the feasibility of the proposed scheme in giving fast control of the induction motor torque.

\section{INDUCTION MOTOR MODEL}

The dynamic model of an induction motor in the stationary reference frame can be written in d-q frame variables. Stator voltage vector $v_{s}$ of the motor can be expressed as follows:

$$
v_{d s}=\frac{d \psi_{d s}}{d t}+R_{s} i_{d s}
$$


$v_{q s}=\frac{d \psi_{q s}}{d t}+R_{s} i_{q s}$

$\overline{v_{s}}=\frac{d \overline{\psi_{s}}}{d t}+R_{s} \overline{i_{s}}$

The stator flux vector $\overline{\psi_{s}}$ and components can be written as

$\psi_{d s}=L_{s} i_{d s}+L_{m} i_{d r}$

$\psi_{q s}=L_{s} i_{q s}+L_{m} i_{q r}$

$\overline{\psi_{s}}=L_{s} \overline{i_{s}}+L_{m} \overline{i_{r}}$

The rotor flux vector $\bar{\psi}_{r}$ and components in the stator reference frame is

$\psi_{d r}=L_{r} i_{d r}+L_{m} i_{d s}$

$\psi_{q r}=L_{r} i_{q r}+L_{m} i_{q s}$

$\overline{\psi_{r}}=L_{r} \bar{i}_{r}+L_{m} \overline{i_{s}}$

where $v_{d s}$ and $v_{q s}$ are the stator voltages; $i_{d s}$ and $i_{q s}$ are the stator currents; $i_{d r}$ and $i_{q r}$ are the rotor currents; $\psi_{d s}$ and $\psi_{q s}$ are the stator fluxes; $\psi_{d r}$ and $\psi_{q r}$ are the rotor fluxes; $\bar{i}_{s}$ and $\bar{i}_{r}$ are the stator and rotor currents vectors; $R_{s}$ is the stator winding resistance., and $L_{s}, L_{r}, L_{m}$ are stator, rotor self inductance and mutual inductance respectively. The electromagnetic torque $T_{e}$ developed by the induction motor in terms of stator and rotor flux vectors can be expressed as

$$
\begin{aligned}
& T_{e}=\frac{3}{2} p \frac{L_{m}}{\sigma L_{s} L_{r}} \overline{\psi_{s}} \times \overline{\psi_{r}} \\
& =\frac{3}{2} p \frac{L_{m}}{\sigma L_{s} L_{r}}\left|\overline{\psi_{s}}\right| \times\left|\overline{\psi_{r}}\right| \\
& =\frac{3}{2} p \frac{L_{m}}{\sigma L_{s} L_{r}}\left|\overline{\psi_{s}}\right| \times\left|\overline{\psi_{r}}\right| \sin \left(\rho_{s}-\rho_{r}\right) \\
& =\frac{3}{2} p \frac{L_{m}}{\sigma L_{s} L_{r}}\left|\overline{\psi_{s}}\right|\left|\bar{\psi}_{r}\right| \sin (\delta)
\end{aligned}
$$

Where $\sigma=1-\frac{L_{m}^{2}}{L_{s} L_{r}}$ is the leakage factor ; $p$ is the number of pole pairs; $\rho_{s}, \rho_{r}$ are stator and rotor flux angles, respectively, and $\delta$ is the torque angle.

From the above equation, clearly, the electromagnetic torque is cross vector product between the stator and rotor flux vectors. Therefore, generally torque control can be performed by controlling torque angle $\delta$ with constant amplitude of the stator and rotor fluxes.
An induction motor model is then used to predict the voltage required to drive the torque and flux to the reference values within a fixed time period. The required voltage is synthesized using space vector modulation. If the inverter is not capable of generating the required voltage, a voltage vector that will drive the torque and flux towards the reference values is used. These above fundamental equations with other equations and SVPWM switching states are used for implementing DTC using SVPWM in three-phase induction motor. A block diagram of this configuration is shown in Figure 1.

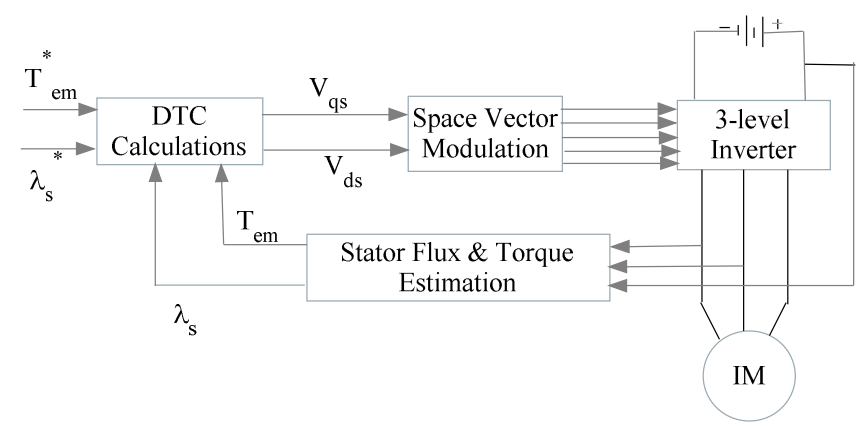

Fig. 1. DTC using space vector modulation block diagram

III. GENERATION OF SPACE VECTOR PWM SIGNALS FOR DTCSVM THREE-LEVEL NPC INVERTER

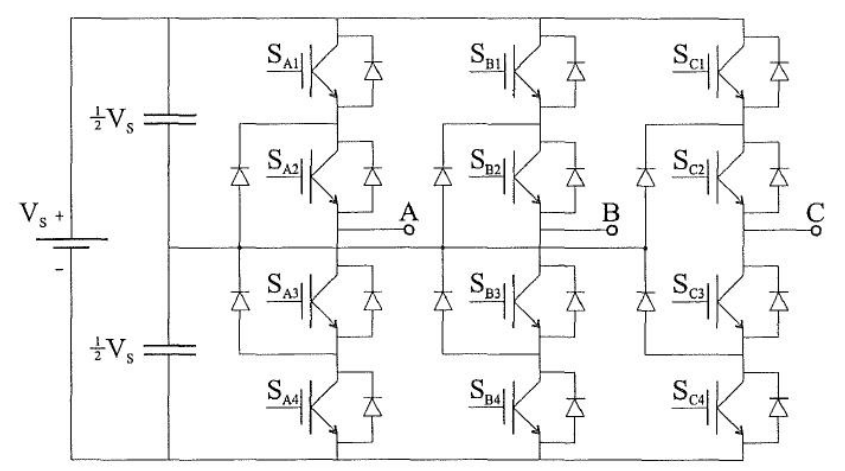

Fig. 2. Three-level neutral point clamped inverter

Figure 2 shows the diagram of three-level neutral point clamped inverter. The operating status of the switches in the NPC inverter can be represented by the switching states shown in Table 1. In case of a two-level inverter there are a total of eight switching-states (six result into active vectors and two result into zero vector). The number of switching states for $n-$ level NPC inverter is given by

$$
\text { Number of switching-states }=n^{3}
$$

Hence, in case of a three-level NPC inverter, there are 27 switching-states and among them, three result in zero vector and 24 result in non-zero (active) vectors. Each switching state (combination of phase/leg switches) produces a defined set of three-phase voltages (eventually, voltage space vector), which 
can be represented in a hexagon form. The SVPWM method is an advanced, computation intensive PWM method and is possibly the best among all the known PWM techniques for variable-frequency drive applications.

TABLE I. SWITCH STATES OF A THREE-LEVEL NPC INVERTER

\begin{tabular}{|l|l|l|l|l|}
\hline \multicolumn{5}{|c|}{ Switch States } \\
\hline $\mathrm{S}_{1}$ & $\mathrm{~S}_{2}$ & $\mathrm{~S}_{3}$ & $\mathrm{~S}_{4}$ & Output Voltage \\
\hline ON & ON & OFF & OFF & $+1 / 2 \mathrm{~V}_{\mathrm{s}}$ \\
\hline OFF & ON & ON & OFF & 0 \\
\hline OFF & OFF & ON & ON & $-1 / 2 \mathrm{~V}_{\mathrm{s}}$ \\
\hline
\end{tabular}

The principle of the SVPWM method is that the command voltage vector is approximately calculated by using three adjacent vectors. The duration of each voltage vectors obtained by vector calculations:

$$
\begin{aligned}
& T_{1} V_{1}+T_{2} V_{2}+T_{3} V_{3}=T_{s} V^{*} \\
& T_{1}+T_{2}+T_{3}=T_{s}
\end{aligned}
$$

Where $V_{1}, V_{2}$ and $V_{3}$ are vectors that define the triangle region in which $V^{*}$ is located. $T_{1}, T_{2}$ and $T_{3}$ are the corresponding vector durations and $T_{s}$ is the sampling time. In a three level inverter similar to a two-level inverter, each space vector diagram is divided into 6 sectors.

For simplicity here only the switching patterns for sector A will be defined so that calculation procedure for the other sector will be similar. Sector A is divided into 4 regions as shown in Figure 3a, where all the possible switching states for each region are given as well. SVPWM for three level inverter can be implemented by using the steps of sector determination, determination of the region in the sector, calculating the switching times $T_{a}, T_{b}, T_{c}$ and finding the switching states.

\section{DESIGN STEPS FOR SVPWM GENERATION}

\section{A. Determining the sector}

$\alpha$ is calculated and then the sector, in which the command vector $V^{*}$ is located can be calculated as:

If $\alpha$ is between $0^{0} \leq \alpha<60^{\circ}$, then $V^{*}$ will be in sector A, If $\alpha$ is between $60^{\circ} \leq \alpha<120^{\circ}$, then $V^{*}$ will be in sector $\mathrm{B}$,

If $\alpha$ is between $120^{\circ} \leq \alpha<180^{\circ}$, then $V^{*}$ will be in sector $\mathrm{C}$,

If $\alpha$ is between $180^{\circ} \leq \alpha<240^{\circ}$, then $V^{*}$ will be in sector D,
If $\alpha$ is between $240^{\circ} \leq \alpha<300^{\circ}$, then $V^{*}$ will be in sector E,

If $\alpha$ is between $300^{\circ} \leq \alpha<360^{\circ}$, then $V^{*}$ will be in sector F.

Determining the region in the sector:

For that:

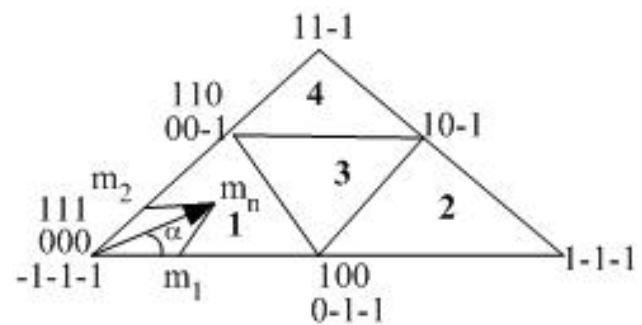

(a)

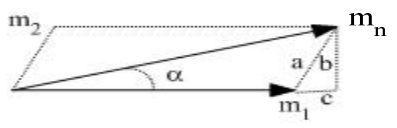

(b)

Fig. 3. Space vector diagram for $\mathrm{m} 1$ and $\mathrm{m} 2$ in sector $\mathrm{A}$.

From Figure $3 \mathrm{~b} m_{2}$ and $m_{1}$ can be calculated as,

$$
\begin{aligned}
& a=m_{2}=\frac{b}{\sin \left(\frac{\pi}{3}\right)}=\frac{2}{\sqrt{3}} b=\frac{2}{\sqrt{3}} \cdot m_{n} \cdot \sin \alpha \\
& m_{1}=m_{n} \cdot \cos \alpha-\left(\frac{2}{\sqrt{3}} \cdot m_{n} \cdot \sin \alpha\right) \cos \left(\frac{\pi}{3}\right) \\
& m_{1}=m_{n}\left(\cos \alpha-\frac{\sin \alpha}{\sqrt{3}}\right)
\end{aligned}
$$

From $m_{1}$ and $m_{2}$ we found,

If $m_{1}, m_{2}$ and $\left(m_{1}+m_{2}\right)<0.5$, then $V^{*}$ is in Region 1 , If $m_{1}>0.5$, then $V^{*}$ is in Region 2 ,

If $m_{2}>0.5$, then $V^{*}$ is in Region 3 ,

If $m_{1}$ and $m_{2}<0.5$ and $\left(m_{1}+m_{2}\right)>0.5$, then $V^{*}$ is in Region 4,

Calculating the switching times, $T_{a}, T_{b}, T_{c}$ :

$T_{a}, T_{b}, T_{c}$ switching times for sector $A$ is given in Table 2 . 
TABLE II. SWITCHING TIMES FOR THE SECTOR

\begin{tabular}{|c|c|c|}
\hline & Region I & Region II \\
\hline $\mathbf{T}_{\mathrm{a}}$ & $1.1 * m^{*} \mathrm{~T}_{\mathrm{s}} * \sin ((\pi / 3)-\alpha)$ & $\mathrm{T}_{\mathrm{s}}(1-1.1 * \mathrm{~m} * \sin (\alpha+\pi / 3))$ \\
\hline $\mathbf{T}_{\mathrm{b}}$ & $\mathrm{T}_{\mathrm{s}} / 2(1-(2 * 1.1 * \sin (\alpha+\pi / 3))$ & $1.1 * \mathrm{~T}_{\mathrm{s}} * \mathrm{~m} * \sin \alpha$ \\
\hline$\overline{T_{c}}$ & $1.1 * \mathrm{~T}_{\mathrm{s}} * \sin \alpha$ & $\mathrm{T}_{\mathrm{s}} / 2\left(\left(2 * 1.1 * \mathrm{~m}^{*} \sin (\pi / 3-\alpha)\right)-1\right)$ \\
\hline & Region III & Region IV \\
\hline $\mathbf{T}_{\mathrm{a}}$ & $\mathrm{T}_{\mathrm{s}} / 2(1-2 * 1.1 * \mathrm{~m} * \sin \alpha)$ & $\mathrm{T}_{\mathrm{s}} / 2(2 * 1.1 * \mathrm{~m} * \sin (\alpha)-1)$ \\
\hline $\mathbf{T}_{\mathrm{b}}$ & $\mathrm{T}_{\mathrm{s}} / 2(2 * 1.1 * \mathrm{~m} * \sin ((\pi / 3)+\alpha)-1)$ & $1.1 * \mathrm{~m}^{*} \mathrm{~T}_{\mathrm{s}} * \sin ((\pi / 3)-\alpha)$ \\
\hline $\mathbf{T}_{\mathrm{c}}$ & $\mathrm{T}_{\mathrm{s}} / 2(1+2 * 1.1 * \mathrm{~m} * \sin (\alpha-(\pi / 3))$ & $\mathrm{T}_{\mathrm{s}}(1-(1.1 * \mathrm{~m} * \sin (\alpha+\pi / 3))$ \\
\hline
\end{tabular}

B. Finding the switching states

By considering the switching transition of only one device at any time, the switching orders given below are obtained for each region located in sector $\mathrm{A}$ if all switching states in each region are used. So, the switching signals for sector $\mathrm{A}$ are:

Region 1: -1-1-1,0-1-1,00-1,000,100,110,111

Region 2: 0-1-1,1-1-1,10-1,100

Region 3: 0-1-1,1-1-1,10-1,100,110

Region 4: 00-1,10-1,11-1,110

1 represents for $+\mathrm{V}_{\mathrm{s}} / 2$ and -1 for $-\mathrm{V}_{\mathrm{s}} / 2$ and 0 represents for 0 state.

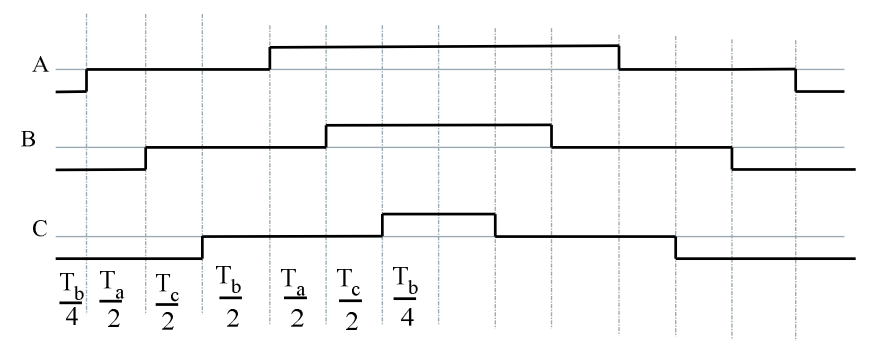

Fig. 4. Switching signals of Sector A in region 1

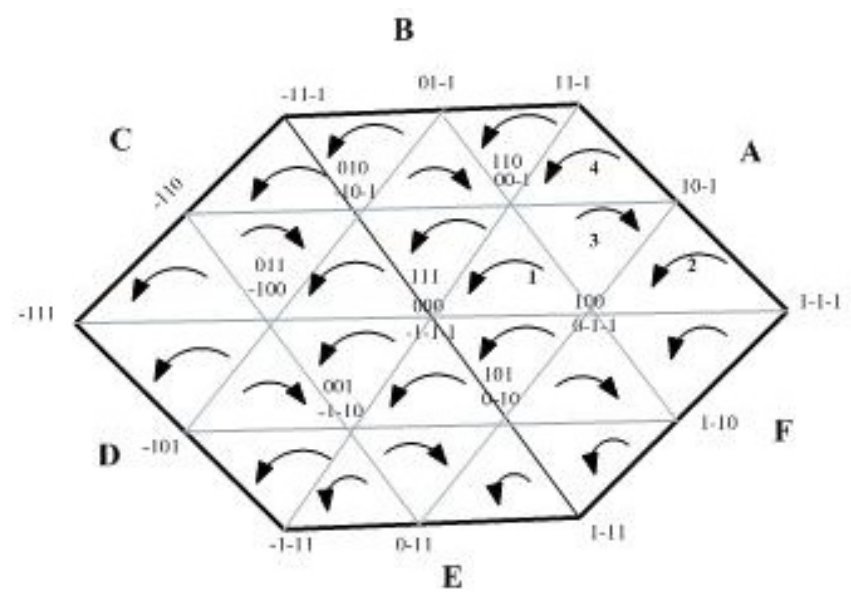

Fig. 5. Switching sequence for three-level SVPWM inverter

Figure 4 represents the switching signals of sector $\mathrm{A}$ in region 1 . In a similar method switching signals of other sectors can be calculated. The complete 27 switching sequence for three-level SVPWM inverter is shown in Figure 5.

\section{SimULATION AND EXPERIMENTAL RESULT WITH DISCUSSION}

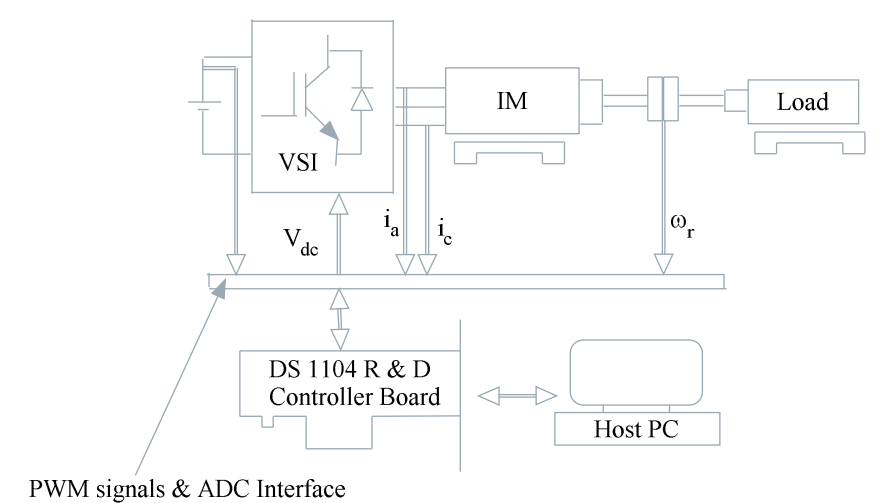

Fig. 6. Block diagram of the experimental set up.

The experimental setup of the proposed control system is represented by the block diagram shown in Figure 6. It consists of a dSPACE DS1104 controller board with TMS320LF2407 slave processor, ADC interface board CP1104, a four pole induction motor with its parameters listed in appendix. A three-phase VSI inverter is connected to the supply $300 \mathrm{~V} \mathrm{dc}$ bus voltage, with a switching frequency of $5 \mathrm{kHz}$.The DS1 104 board is installed in pentium IV $1.5 \mathrm{GHz}$ PC for software development and results visualization. The control program is written in MATLAB/Simulink real time interface with sampling time of $100 \mu \mathrm{s}$. The experimental results are illustraed in Figures 7, 8 and 9. 


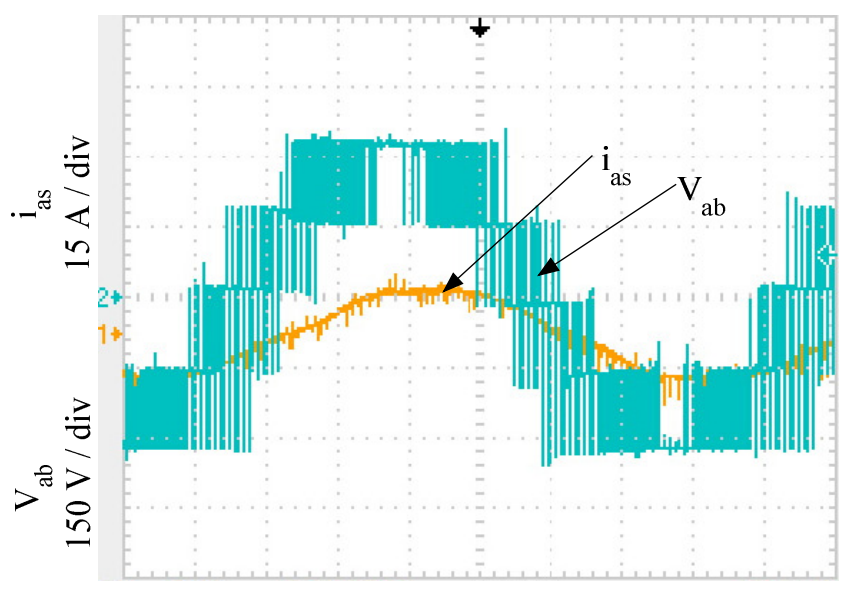

$100 \mathrm{~ms} / \mathrm{div}$

Fig. 7. Experimental results: Stator line voltage and current (three-level scheme).

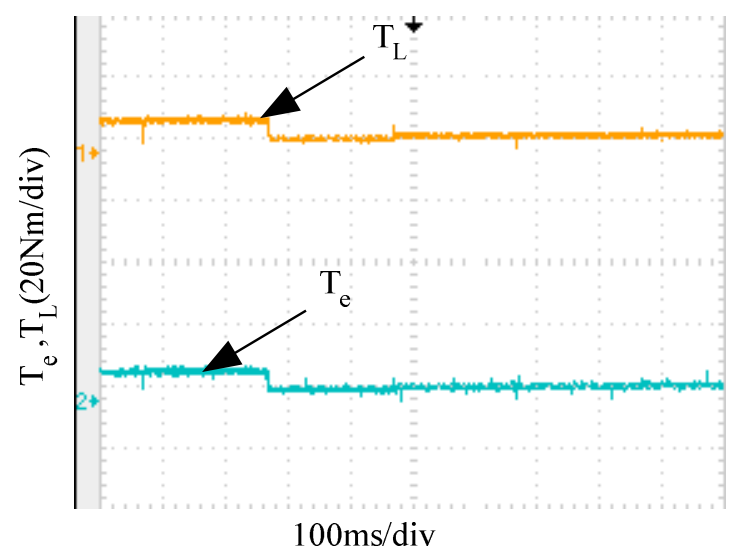

Fig. 8. Experimental results: Reference and actual torques (three-level scheme)

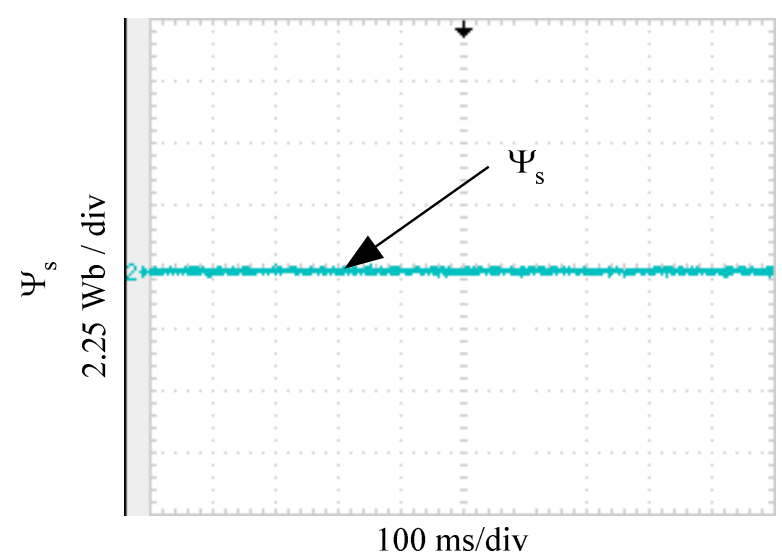

Fig. 9. Experimental results: steady-state stator flux (three-level scheme)

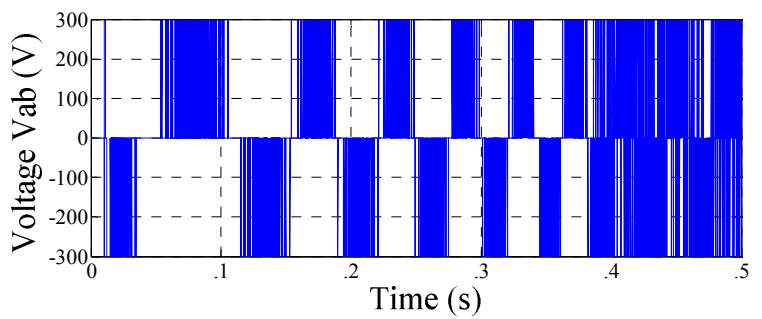

Fig. 10. Simulation results: stator line voltage (two-level scheme).

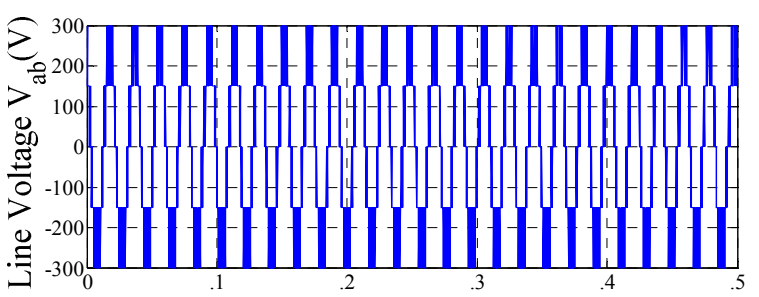

Time (s)

Fig. 11. Simulation results: stator line voltage (three-level scheme).

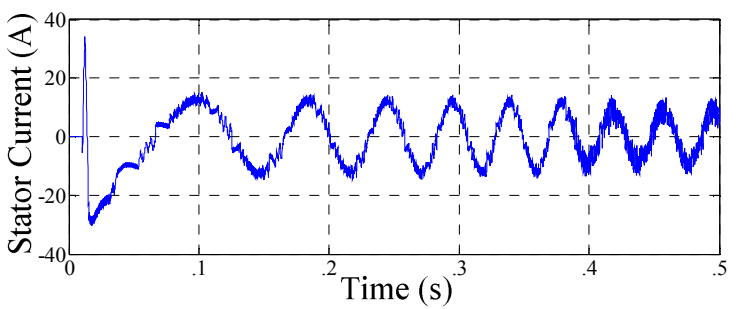

Fig. 12. Simulation results: stator current (two-level scheme)

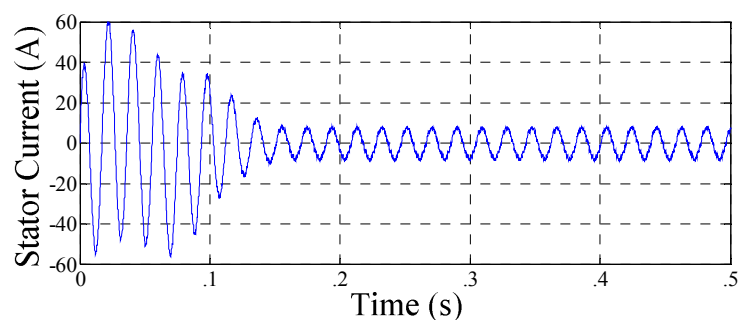

Fig. 13. Simulation results: stator current (three-level scheme).

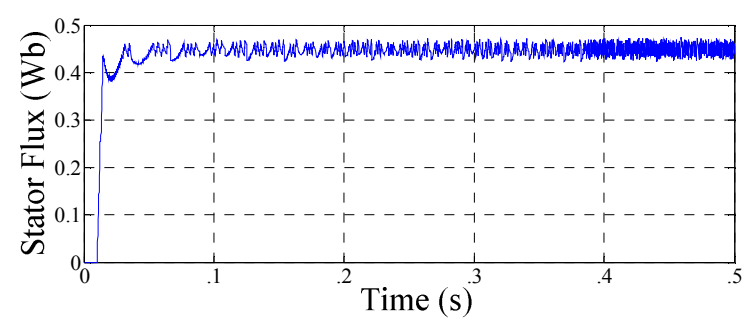

Fig. 14. Simulation results: stator flux (two-level scheme). 


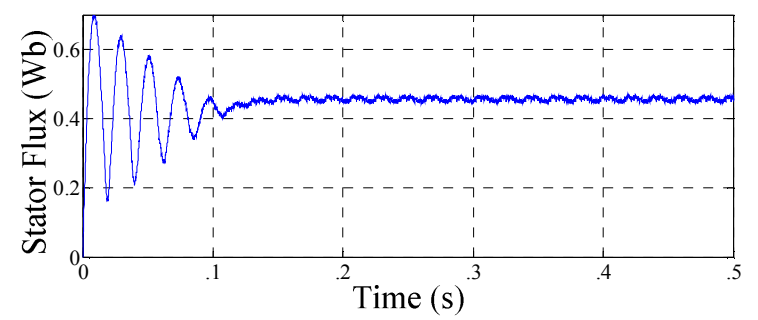

Fig. 15. Simulation results: stator flux (three-level scheme).

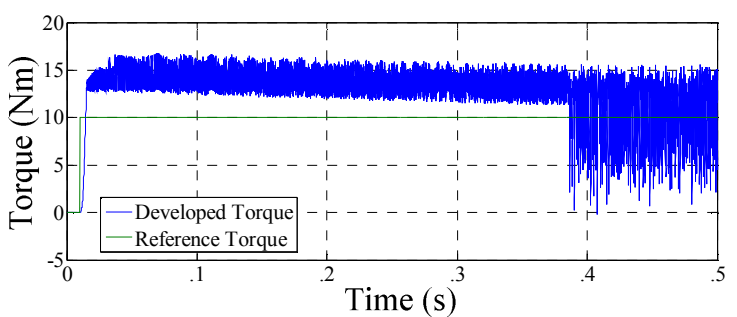

Fig. 16. Simulation results: developed torque and reference torque (twolevel- scheme).

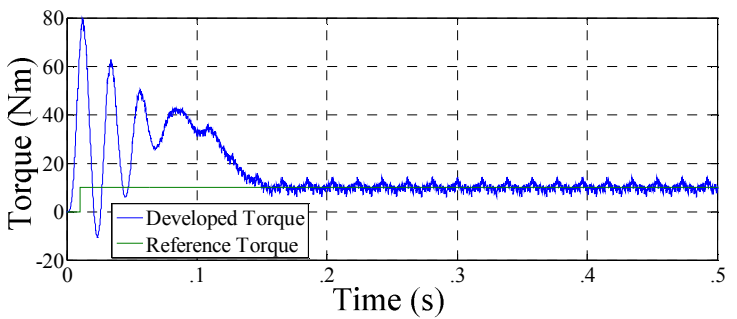

Fig. 17. Simulation results: developed torque and reference torque (threelevel- scheme).

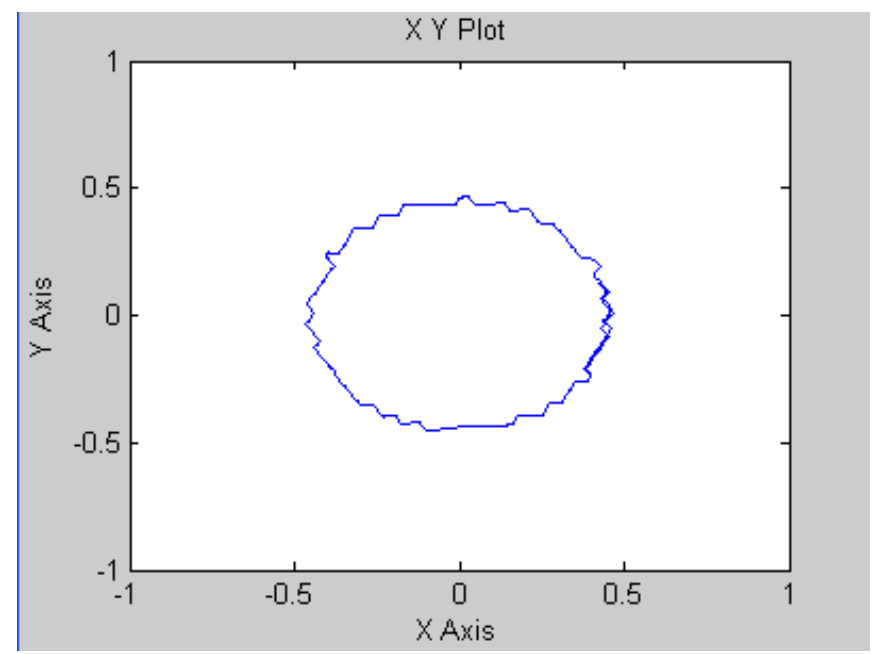

Fig. 18. Steady-state stator d-q axis flux locus (two-level scheme).

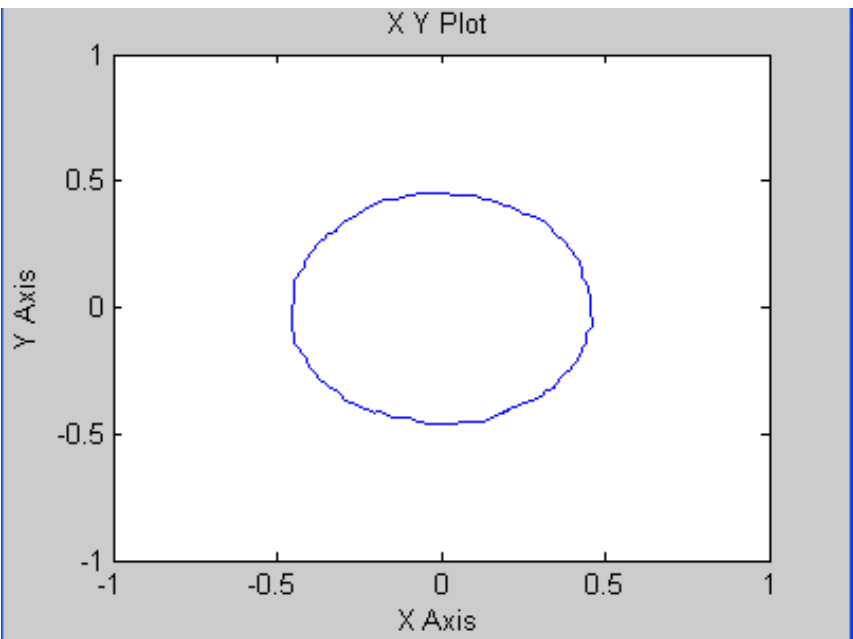

Fig. 19. Steady-state stator d-q axis flux locus (three-level scheme).

The DTC schemes were simulated using the MATLAB/Simulink environment and the simulation results were found to be in agreement with the experimental results. Figure 10 represents the stator line voltage of two-level classical DTC and Figure 11 represents the line voltage of three-level SVM-DTC. The percentage of THD of stator line voltage of two-level DTC is $106.12 \%$ and that of three-level DTC is $34.48 \%$. Figure 12 and Figure 13 represent the stator current of two-level and three-level DTC respectively. The percentage of THD of stator current in two-level scheme is $58.12 \%$ and that of three-level is $28.09 \%$. During transient study of stator current (two-level), current was zero up to 0.01 second. At 0.01 second, current suddenly rises to $35 \mathrm{~A}$ and then decreases to $-30 \mathrm{~A}$ and come to steady-state at 0.05 seconds. In three-level DTC, there is no current zero state but initially stator transient current rises to $60 \mathrm{~A}$ then come to steady-state at 0.1 second and flows smoothly. Figure 14 and Figure 15 shows the stator flux of two-level and three-level schemes respectively. Flux ripple of two-level is $0.03 \mathrm{~Wb}$ and that of three-level is $0.02 \mathrm{~Wb}$ under steady-state operation. Figure 16 and Figure 17 represent the torque response of two and threelevel schemes respectively. The reference torque is taken as 10 $\mathrm{Nm}$. The step rise in torque command is from $0 \%$ to $100 \%$ of rated torque $(10 \mathrm{Nm})$. The torque ripple for two-level schemes is found to be $13 \mathrm{Nm}$ and that of three-level scheme is $7.5 \mathrm{Nm}$ under steady-state operation. Figure 18 represents the steadystate stator $\mathrm{d}-\mathrm{q}$ axis flux locus for two-level inverter and Figure 19 represents for three-level inverter. The stator d-q axis flux locus in the three-level scheme is more uniform compared to the two-level scheme. DTC-SVM with three-level inverter gives lower THD of voltage and current and reduced ripple in flux and torque compared to the classical two-level DTC. Therefore, it can be concluded that the DTC-SVM with threelevel inverter gives better results than classical two-level DTC in all aspects.

\section{CONCLUSION}

This paper has reviewed different DTC strategies for PWM inverter-fed AC motor drives. The DTC represents a viable alternative to FOC, another general philosophy for controlling 
AC drives. The main features of DTC can be summarized as follows:

- According to adopted definition, DTC operates with closed torque and flux loops but without current controllers

- DTC needs stator flux and torque estimation and therefore, is not sensitive to rotor parameters

- DTC has fast dynamic response,

- DTC has simple and robust control structure; however, the performance of DTC strongly depends on estimation accuracy of the stator flux and motor torque.

DTC strategies using space vector modulation technique with detailed generation of space vector modulating signals have been discussed. Constant switching frequency SVPWM DTC schemes considerably improve the drive performance in terms of reduced torque and flux pulsations, reliable start up, well-defined harmonic spectrum and radiated noise. Therefore, SVPWM-DTC is an excellent solution for general purpose IM drives in a very wide power range. The short sampling time required by the switching table DTC schemes makes them suited to very fast torque and flux controlled drives in spite of the simplicity of the control algorithm. In conclusion, it is believed that the DTC principle will continue to play a strategic role in the development of high performance drives.

\section{APPENDIX}

\section{INDUCTION MOTOR RATING AND PARAMETERS (REFERRED TO STATOR)}

$\begin{array}{ll}\text { Power } & 1.5 \mathrm{~kW} \\ \text { Voltage(L-L) } & 415 \mathrm{~V} \\ \text { Current } & 2.6 \mathrm{~A} \\ \text { Frequency } & 50 \mathrm{~Hz} \\ \text { Rated Torque } & 10 \mathrm{Nm} \\ \text { Speed } & 1415 \mathrm{rpm} \\ \text { Stator Resistance }\left(\mathrm{R}_{\mathrm{s}}\right) & 0.55 \Omega \\ \text { Rotor Resistance }\left(\mathrm{R}_{\mathrm{r}}\right) & 0.78 \Omega \\ \text { Stator Leakage Inductance }\left(\mathrm{L}_{\mathrm{ls}}\right) & 0.00288 \mathrm{H} \\ \text { Rotor Leakage Inductance }\left(\mathrm{L}_{\mathrm{lr}}\right) & 0.00286 \mathrm{H} \\ \text { Mutual Inductance Between } & 0.0905 \mathrm{H} \\ \text { Stator and rotor }\left(\mathrm{L}_{\mathrm{m}}\right) & \\ \text { Moment of Inertia }(\mathrm{J}) & 0.019 \mathrm{Kg}-\mathrm{m}^{2} \\ \text { Number of poles } & 4\end{array}$

FRONT-END CONVERTER PARAMETERS

$\begin{array}{ll}\text { Input supply phase voltage } & 145 \mathrm{~V}(\mathrm{rms}), 3 \mathrm{ph}, 50 \mathrm{~Hz} \\ \text { DC link voltage } & 300 \mathrm{~V} \\ \text { Synchronous link inductor } & 8.0 \mathrm{mH} \\ \text { DC link capacitor } \mathrm{C}_{1}=\mathrm{C}_{2} & 2200 \mu \mathrm{F}\end{array}$

\section{REFERENCES}

[1] I. Takahashi, T. Noguchi, "A new quick-response and high- efficiency control-strategy of an induction motor", IEEE Transactions on Industry Applications, Vol. IA 22, No. 5, pp. 820-827, 1986.

[2] M. Depenbrock, "Direct self-control (DSC) of inverter-fed induction machine", IEEE Transactions on Power Electronics, Vol. 3, No. 4, pp. 420-429, 1988.

[3] G. Abad, M. A. Rodriguez, J. Poza, "Two-level VSC based predictive direct torque control of the doubly fed induction machine with reduced torque and flux ripples at low constant switching frequency", IEEE Transactions on Power Electronics, Vol. 23, No. 3, pp. 1050-1061, 2008.

[4] D. Casadei, G. Serra, A. Tani, "Improvement of direct torque control performance by using a discrete SVM technique", in proc. PESC 98 Record Power Electronics Specialists Conference $29^{\text {th }}$ Annual IEEE, Vol. 2, pp. 997-1003, 1998.

[5] G. S. Buja, M. P. Kazmierkowski, "Direct torque control of PWM inverter-fed AC motors - A survey", IEEE Transactions on Industrial Electronics, Vol. 51, No. 4, pp. 744-757, 2004.

[6] B. P. Panigrahi, D. Prasad, S. Sengupta, “ A simple hardware realization of switching table based direct torque control of induction motor", Electric Power Systems Research, Vol. 77, No. 2, pp. 181-190, 2007.

[7] M. K. Sahu, B. P. Panigrahi, A. K. Panda, "An utility friendly direct torque control technique of three phase induction motor with two-level inverter using 180 degree conduction mode", International Journal of Engineering Science and Technology, Vol. 3, No. 5, pp. 4120-4130, 2011.

[8] J. Rodriguez, S. Bernet, B. Wu, J. O. Pontt, S. Kouro, "Multilevel voltage-source-converter topologies for industrial medium-voltage drives", IEEE Transactions on Industrial Electronics, Vol. 54, No. 6, pp. 2930-2945, 2007.

[9] W. Yao, H. Hu, Z. Lu, "Comparisons of space vector modulation and carrier-based modulation of multilevel inverter", IEEE Transactions on Power Electronics, Vol. 23, No. 1, pp. 45-51, 2008.

[10] S. Busquets, S. Alepuz, J. Bordonau, J. Peracaula, "Voltage balancing control of diode-clamped multilevel converters with passive front-ends", IEEE Transactions on Power Electronics, Vol. 23, No. 4, pp. 1751$1758,2008$.

[11] Y. Zhang, Z. Zhao, "Study on capacitor voltage balance for multilevel inverter based on a fast SVM algorithm", Proceeding of the CSEE(in Chinese), Vol. 26, No. 18, pp. 71-76, 2006.

[12] L. Dalessandro, S. D. Round, J. W. Kolar, "Center-point voltage balancing of hysteresis current controlled three-level PWM rectifiers", IEEE Transactions on Power Electronics, Vol. 23, No. 5, pp. 2477-2488, 2008.

[13] P. K. Steimer, J. K. Steinke, H. E. Gruning, "A reliable , interface friendly medium voltage drive based on the robust IGCT and DTC technologies", in $34^{\text {th }}$ IAS Annual Meeting Industry Applications Conference Record of the 1999 IEEE, Vol. 3, pp. 1505-1512, 1999.

[14] K. B. Lee, J. H. Song, I. Choy, J. Y. Yoo, "Torque ripple reduction in DTC of induction motor driven by three-level inverter with low switching frequency", IEEE Transactions on Power Electronics, Vol. 17, No. 2, pp. 255-264, 2002.

[15] A. Gharakhani, A. Radan, "Analytical study of affecting characteristic of voltage vectors of a three-level NPC inverter on torque and flux of DTC controlled drives", in proc. IEEE International Electric Machines Drives Conference IEMDC' 07, Vol. 1, pp. 754-759, 2007.

[16] G. Brando, R. Rizzo, "An optimized algorithm for torque oscillation reduction in DTC induction motor drives using 3-level NPC inverter", in Proc. IEEE International Symposium on Industrial Electronics, Vol. 2, pp. 1215-1220, 2004.

[17] X. del Toro Garcia, A. Arias, M. G. Jayne, and P.A. Witting, "Direct torque control of induction motors utilizing three-level voltage source inverters", IEEE Transactions on Industrial Electronics, Vol. 55, No. 2, pp. 956-958, 2008.

[18] Y. Zhang, J. Zhu, Z. Zhao, W. Xu, D. G. Dorrell, “An improved direct torque control for three-level inverter-fed induction motor sensorless 
drive", IEEE Transactions on Power Electronics, Vol. 27, No. 3, pp. 1502-1513, 2012.

[19] Y. Zhang, Z. Zhao, W. Xu, D. G. Dorrell, "Speed sensorless direct torque control of 3-level inverter-fed induction motor drive based on optimized switching table", in Industrial Electronics Society, 2009. IECON' 09. The $35^{\text {th }}$ Annual Conference of the IEEE, pp. 1318-1323, 2009.

[20] A. Sapin, P. K. Steamer, J. J. Simond, “ Modeling simulation and test of a three-level voltage-source-inverter with output LC filter and direct torque control", IEEE Transactions on Industry Applications, Vol. 43, No. 2, pp. 469-475, 2007.

[21] Y. Zhang, Z. Jhao, T. Lu, L. Yuan, “ Sensorless three-level inverter-fed induction motor drive based on indirect torque control", in Proc. IEEE $6^{\text {th }}$ International Power Electronics and Motion Control Conference IPEMC’ 09, pp. 589-593, 2009.

[22] G. Buja, M. P. Kazmierkowski, "Direct torque control of PWM inverterfed AC motor- a survey", IEEE Transactions on Industrial Electronics, Vol. 51. No. 4, pp. 744-757, 2004.

[23] T. G. Habetler, F. Profumo, M. Pastorelli, L. Tolbrt, " Direct torque control of Induction machines using space vector modulation", IEEE Transaction on Industry Applications, Vol. 28, No. 5, pp. 1045-1053, 1992.

[24] J. L. Romeral, A. Arias, E. Aldabas, M. G. Jayne, "Novel direct torque control(DTC) scheme with fuzzy adaptive torque ripple reduction", IEEE Transactions on Industrial Electronics, Vol. 50, No. 3, pp. 487 492, 2003.

[25] I. G. Bird, H. Zelaya De La Parra, "Fuzzy logic torque ripple reduction for DTC based AC Drives", Electronics Letter, Vol. 33, No. 17, pp. 1501-1502, 1997.

[26] J. Kang, S. Sul, "New direct torque control of induction motor for minimum torque ripple and constant switching frequency", IEEE Transactions on Industrial Electronics, Vol. 35, No. 5, pp. 1076-1082, 1999.

[27] Suresh. Mikkili, A. K. Panda, "SHAF for mitigation of current harmonics using p-q method with PI and fuzzy controllers", Engineering, Technology \& Applied Science Research, Vol. 1, No. 4, pp. 98-104, 2011.

[28] A. Gupta, A. M. Khambadkone, "A space vector PWM scheme for multilevel inverters based on two-level space vector PWM", IEEE Transactions on Industrial Electronics, Vol. 53, No. 5, pp. 1631-1639, 2006.

\section{AUTHORS PROFILE}

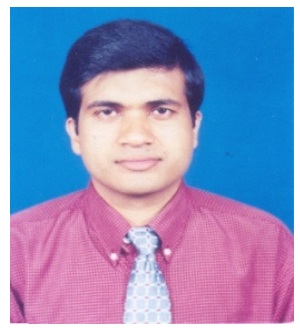

Manoj Kumar Sahu was born in 1975, he received a B.E. degree in Electrical Engineering from University College of Engineering (at present VSSUT University), Burla, Sambalpur University, India in 1997. He received the M.Tech (Power Electronics and Drives) from KIIT University, Bhubaneswar, India in 2007. At present, he is continuing his Ph.D. in Electrical Engineering at Utkal University, India, and holds the position of Associate Professor and HOD at Hi-Tech College of Engineering under Biju Pattnaik University and Technology (BPUT), Rourkela, India. He has fifteen years of experience in teaching and research. He has published over ten research papers in various journals and conferences proceedings. His research interests include electrical machines, power electronics, electrical drives and power systems.

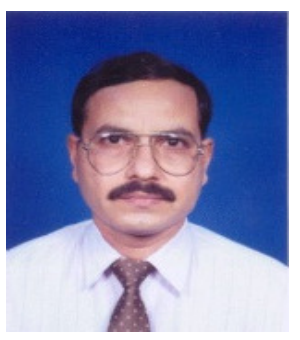

Anup Kumar Panda was born in 1964, he received a BSc. degree in Electrical Engineering from the University College of Engineering (at present VSSUT University), Burla, Sambalpur University, India in 1987. He received a M.Tech (Power Electronics and Drives) from the Indian Institute of Technology, Kharagpur, India in 1993 and a Ph.D. in 2001 from Utkal University. He has twenty five years of experience in teaching and research. He has published over forty five articles in journals and conferences. At present he is continuing as a professor in the department of electrical engineering at the National Institute of Technology, Rourkela. His research interests include power electronics, Power quality improvements in power system and electrical drives.

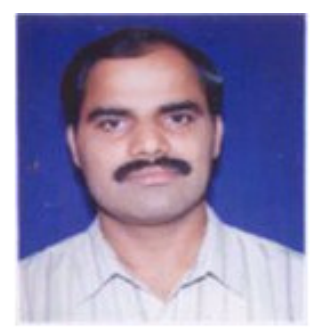

Bibhu Prasad Panigrahi was born in 1968, he received a B.Sc. degree in Electrical Engineering from the University College of Engineering (at present VSSUT University), Burla, Sambalpur University, India in 1989 and a M.Tech. (Power Electronics and Power Systems) from the Indian Institute of Technology, Bombay, India in 1997. He obtained his Ph.D. degree in Electrical Engineering from the Indian Institute of Technology, Kharagpur in 2007. He has twenty three years of experience in teaching and research. At present he is continuing as Professor and HOD in Electrical Engineering department at Indira Gandhi Institute of Technology, Sarang, Dhenkanal, India. He has published over thirty research papers in various journals and conferences proceedings. His research interest includes electrical machines, power electronics, electrical drives and power systems. 